\title{
An interview with Sergio Martino: An American in Rome
}

Giulio Olesen, Bournemouth University

\section{Introduction}

Sergio Martino (born Rome, 1938) is a film director known for his contribution to 1970s and 1980s Italian filone cinema. His first success came with the giallo Lo strano vizio della Signora Wardh (Next!) (1971), from which he moved to spaghetti westerns (Mannaja [A Man Called Blade], 1977), gialli (I corpi presentano tracce di violenza carnale [Torso], 1973), poliziotteschi (Milano trema: la polizia vuole giustizia [The Violent Professionals], 1973), horror movies (La montagna del dio cannibale [The Mountain of the Cannibal God], 1978; L'isola degli uomini pesce [Island of Mutations], 1979), science fiction movies (2019, dopo la caduta di New York [2019, After the Fall of New York], 1983) and comedies (Giovannona Coscialunga disonorata con onore [Giovannona Long-Thigh], 1973). His works witness the hybridization of international and local cinematic genres as a pivotal characteristic of Italian filone cinema.

This face-to-face interview took place in Rome on 26 October 2015 in the venues premises of Martino's production company, Dania Film, and addresses his horror and giallo productions. Much scholarship analyses filone cinema under the lens of cult or transnational cinema studies. In this respect, the interview aims at collecting Martino's considerations regarding the actual state of debate on Italian filone cinema. Nevertheless, e Emphasis is put on a different approach towards this kind of cinema; an approach that aims at analysing filone cinema for its capacity to represent contemporaneous issues and concerns.

Accordingly, introducing Martino's relationship with Hollywood, the interview focuses on the way in which his horror movies managed to intercept $\underline{\text { register fears and }}$ neuroses of Italian society. The director explores the chaotic system of production of filone 
cinema. Thus, he faces the struggle to organize it as an industry, contrasting the negative approach of the critics towards a cinema devoted to entertainment in a highly politicized period of Italian history. Sexual liberation, political violence, corrupted authorities and bloodthirsty criminals provided the inspiration for a director who managed to-merged Italian craftsmanship to-with the professionalism achieved in his experience in the United States.

Giulio Olesen: Maestro Martino, your movies and Italian filone cinema are experiencing a substantial critical revaluation after being critically scorned. In your opinion what are the reasons behind the rediscovery of Italian filone cinema?

Sergio Martino: Firstly, I have to say that if my movies and Italian filone movies have been criticized too much in the past, perhaps nowadays we are going too far in the opposite direction. Nonetheless, the difference in reception between Italy and foreign countries was due to the prejudices of the Italian critics against our movies. However, although critics in Italy aimed to wipe out our kind of cinema, far-sighted entrepreneurs understood the potential of these films. A producer once told me that a businessman from northern Italy paid one billion lire for his old films. Thanks to oTogether with my movies and with those of my colleagues, theyur movies he became an importantbuilt part of the programming schedule of his fledgling private television networks. Abroad, on the other hand, the potential of videocassettes was discovered early on: many films were bought and conserved to be released in that format. Therefore, their marketing continued, contributing to their international rediscovery. In Italy our filmed material was often lost or abandoned in cellars where it ended up damaged.

Commented [JW1]: Does this make sense?

Commented [GO2]: Does it make sense now? Probably something get lost with the translation. I could cut the word "fledgling" but I think is important. It would require further explanation but it is intended to highlight the fact that we are talking about a different historical context (that of the death of Italian filone cinema and of Berlusconi's private televisions).

Commented [AF3]: No. Glulio, can you rephrase this? 
G.O.: The close relationship between Italian filone cinema and Hollywood cinema is often emphasized. What was your relationship with American cinema?

S.M.: Actually, the director who influenced me most was Costa-Gavras, while Peckinpah and Spielberg were the American directors I especially loved. Anyway, budget limitations differentiated our genre films from the American ones. Our cinema collapsed when our handcrafted special effects had to compete with Hollywood digital special effects and politicians were not able to stimulate our technological progress. The cars that exploded in our movies were old, unlike those of Dirty Harry (Siegel, 1971), but the final effect was the same. In any case, in my most productive years, I became American, because shooting these scenes required a degree of precision and attention that I had acquired shooting in the United States. Nonetheless, it is absurd to think how much we have risked making our films.

G.O.: The female body has a significant importance in your gialli. Above all, promiscuity is often used as a trigger to justify the psychotic retaliation of the villains. To what extent did the evolution of the role of women in the 1970s shape the psychological and emotive triggers within your films?

S.M.: Promiscuity was a central element. A bit of morbidity, even perverse, justified the death of the characters. Anyhow, I never loved shooting erotic scenes. They are one of the hardest things to shoot, both for directors and actors, because obviously you feel uncomfortable. Many actresses used patches to hide their private parts $s_{2}$ othersf wanted to keep their arms raised in nudity scenes in order-to keep-hold their breast up liftedand look younger. It was simply the resulta consequence of stardomthe star system. In fact, everything was often the result of a compromise, with the specific task, in the case of my cinema, not to jeopardize the box office returns. Therefore, the attempts to intellectualize murder or to make it more psychologically acceptable aroise from the fact that certain characters must have

\section{Commented [JW4]: Perversion?}

Commented [GO5]: Here Martino was using the adjective perverse to qualify "morbidity" ("un po' di morbosità, anche perversa"). Nonetheless, for the sake of clarity I could just put "even perversion", or "A bit of perverse morbidity". What do you think?

\section{Commented [JW6]: Unclear}

Commented [GO7]: The breast of young women stays up The breast of more mature women goes down... Martino wanted to say that actresses, during erotic scenes, wanted to be shot with their arms raised, resulting in their breast being lifted up and actresses looking younger.

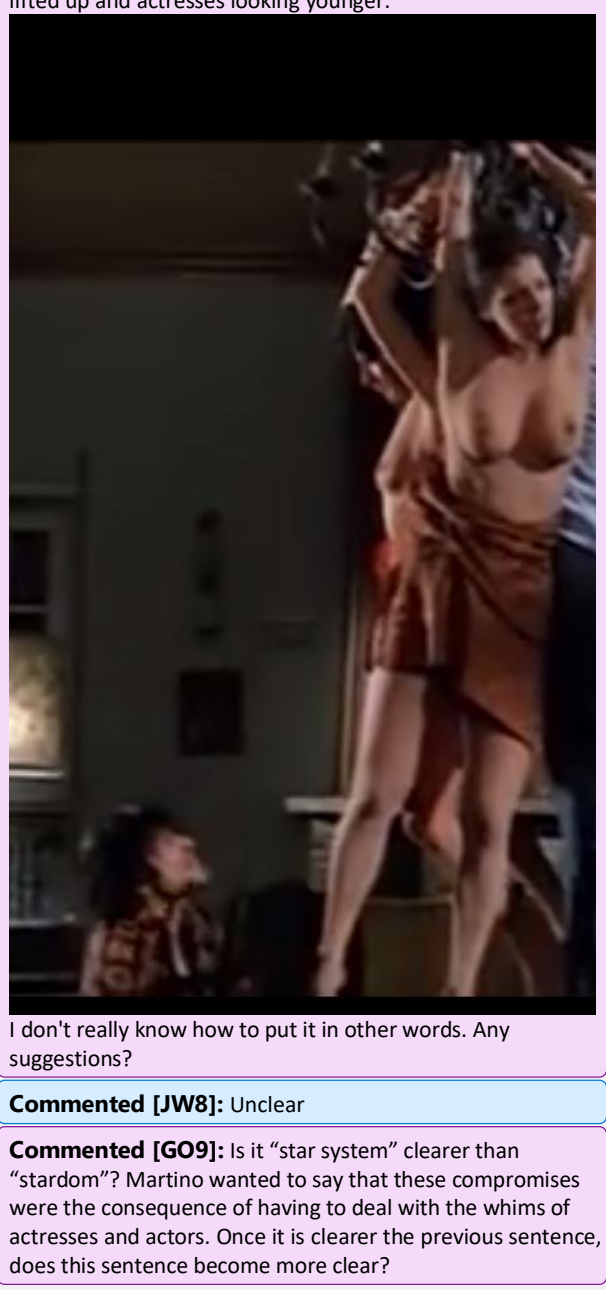


perversions to justify their deaths. In Torso (1973), for example, Suzy Kendall never has sex scenes, and she is the only character that does not die. The others had sexual perversions; thus, potentially, the audience could participate more in their deaths, especially in the Italian context, where there was a contested wave of sexual liberation in progress.

G.O.: The media play a significant role in your movies, especially as a filter, often negative, between the events, the characters, and public opinion. Could you explain the reasons for this approach?

S.M.: Newspapers were always a source of inspiration for Italian genre films. In some cases, I commented on their tendency to sensationalize the news, but they were, above all, a source of inspiration. Actually, in Torso, the idea for the technique used by the killer to slice his victims came from a major news story. A man killed his in-laws in an apartment in Rome. Then, he dissected the bodies and brought them day by day out of this apartment on the outskirts of Romean outskirts. It fascinated me because the man was very fatherly: picking up his son from school and offering him an ice cream, before carrying on with the dissection of his in-laws, leaving the child downstairs. There were also movies that inspired our films. With Torso, I was inspired by Richard Fleischer's See No Evil (1971) and I tried to create a plot that could combine the fascination of this film with the Roman news.

G.O.: International critics and fans have largely focused on the portrayal of violence in Italian filone films, and this has overshadowed other elements of your movies. Referring to your Island of Mutations (1979) - to which some violent scenes were added for international markets - to what extent were that film's violent excesses based on commercial demands?

S.M.: I do not know what happened to Island of Mutations. Foreign distributors often made changes without our consent, but we were a minor film industry and we accepted many 
compromises. The use of violence was often instrumental to production demands, as we had to accept the cheapest solutions. Meanings have been given to certain situations in my movies when, in fact, they were just attempts to resolve problems from time to time. Sometimes, erotic or violent scenes were shot in a deliberately sloppy way to meet the censorship cuts. Distributors had their demands: the ban on minors under eighteen years of age was a key vehicle to attract audiences, and violence had the same profitable value as swear words do in comedy. Nowadays, however, these scenes have been added again, giving a different effect to some of them. Other times, production and distribution needs influenced the content and structure of the movies: Assassinio al cimitero etrusco (The Scorpion with Two Tails) (Martino, 1982), for instance, was initially shot as a television series, then cut and completed with connecting scenes.

G.O.: Italian filone films are often said to be cinematic products for 'distracted' audiences of second- and third-run cinemas. Do you agree with this assertion? Who was the target audience of your movies?

S.M.: I never rely on a specific target; I imagined an audience that was going to the cinema not to get bored. This did not mean that they were not culturally evolved. When I walked into theatres, I often saw upper-class people that were there to enjoy themselves, perhaps with their wife looking for strong sensations. In fact, my films were also shown in the first run cinemas and I often went there to see the reactions of the audiences. At that time, the ritual of going to the cinema in the evening was not peculiar just to the working classes. If audiences did not choose American films, it was thanks also to Dario Argento, who was the first to succeed in Italy with gialli. Actually, when I did my first giallo, Next! (1971), Argento had recently released his first movie, and my film targeted the same audience of first run cinemas. 
G.O.: In your films, from gialli to action movies, a contemptuous disdain towards wealth is expressed by different characters - as in The Mountain of the Cannibal God (1978) and in The Scorpion with Two Tails (1982), and in the character of Edmund Rackham in Island of Mutations (1979). Could you explain this approach to the construction of your characters?

S.M.: This was part of the context of Italy in the 1970s. At the time, driving around in a nice car was considered a sin. There were kidnappings and people were afraid to show their wealth. Many times our films were criticized for the same original sin of using certain elements for commercial purposes, to make money. The movies were produced in a context in which wealth was identified as a negative value, and I often exploited this feature, in horror as in action movies.

G.O.: Your horror movies, as well as your gialli, feature a substantial lack of confidence in public authorities. To what extent did the conflictual relationship between Italians and their state during the peak of your career influence your representation of public authorities?

S.M.: This too was a feature of the Italian context. Everyday life was accompanied by incessant news of corruption, and protest had reached its peak. Later on, the Red Brigades began to kill people who had little to do with their claims, contributing to the exasperation of many who did not see effective actions from the authorities. Many of my gialli were set abroad because distributors had prejudices against the Italian police in films, as it was not considered credible. Then Stefano Vanzina came out with La polizia ringrazia (Execution Squad) (1972) and legitimized the presence of Italian police in cinema.

G.O.: Your horror movies were shot mostly at the end of the 1970s. Did the production of your movies ever suffer from censorship or other limitations due to the escalation of violence in Italian society? 
S.M.: No, nothing special. The tensions of the Italian context contributed to many plots: Piazza Fontana and all the Italian mysteries have been a source of inspiration for numerous films. In those years I attempted to intercept the anger and fear of the people who witnessed these terrible events from the sidelines. We tried to transfer this frustration into our films, horror, gialli or polizieschi, sometimes even exploiting it. Nevertheless, the Americans were the first to use this emotional device. In any case, our films needed some sort of 'balance': between a setting that could be assimilated as reactionary or fascist - responding to widespread feelings in the Italian population through the rhetoric of the vigilante - and items you might define as leftist - connected with protest movements. In the 1970s the climate in Italy was such that you could risk being shot by radicals, a consideration that influenced these balancing operations within the films.

G.O.: After its gradual disappearance, what do you think was the greatest contribution of Italian filone cinema to Italian and international cinema?

S.M.: The major contribution was to have arranged our film production at an industrial level, for the first time in Italy. Thus, we were able to create the conditions for lots of new talents to have the chance to express themselves. In addition, the fact that I inspired some of Tarantino's films was a great satisfaction. When Tarantino playfully knelt in front of me, and in front of all my colleagues, at the Venice Film Festival, as I always had a very cynical and ironic outlook on life, I thought: is he kidding me? But in reality it was a belated recognition. It was like sitting on the riverbanks and seeing the body of the enemy float by.

G.O.: What do you think is the state of Italian horror cinema nowadays?

S.M.: I like the young Alex Infascelli. The generation of film-makers of ten years ago grew up with the idea that our kind of cinema had to be swept away. Now it is slowly being re- 
evaluated and, probably, someone will do some remakes much nicer and with more resources than I had. My brother, Luciano Martino, persevered on producing genre films, but I understood early on that there were no longer the conditions to spend money in genre cinema. Nonetheless, we made it possible for new authors, such as the Manetti Bros., to express themselves: the title of their movie Song'e Napule ${ }^{1}$ (2013) was my brother's idea and an insight of the old school helped them to succeed as they deserve. Here, for better or worse, we tried to create a certain kind of cinema, directed at audiences in search of excitement, sometimes with an excessive indulgence towards violence or eroticism. Anyway, I don't think I deserve to be stoned for this.

\section{References}

Fleischer, Richard (1971), See No Evil, UK: Columbia.

Manetti Bros. (2013), Song'e Napule, Italy: Devon Cinematografica.

Martino, Sergio (1971), Lo strano vizio della Signora Wardh (Next!), Italy and Spain: Copercines, Cooperativa Cinematográfica, Devon Film.

(1973), I corpi presentano tracce di violenza carnale (Torso), Italy: Compagnia Cinematografica Champion.

(1973), Milano trema: la polizia vuole giustizia (The Violent Professionals), Italy: Compagnia Cinematografica Champion. 
(1973), Giovannona Coscialunga disonorata con onore (Giovannona Long-Thigh), Italy: Dania Film.

(1977), Mannaja (A Man Called Blade), Italy: Devon Film.

(1978), La montagna del dio cannibale (The Mountain of the Cannibal God), Italy:

Dania Film, Medusa Distribuzione.

(1979), L'isola degli uomini pesce (Island of Mutations), Italy: Dania Film, Medusa Distribuzione.

(1982), Assassinio al cimitero etrusco (The Scorpion with Two Tails), Italy and France:

Dania Film, Medusa Distribuzione, Publikampas, Les Films Jacques Leitienne.

(1983), 2019, dopo la caduta di New York (2019, After the Fall of New York), Italy and France: Nuova Dania Cinematografica, Medusa Distribuzione, Les Films du Griffon.

Siegel, Don (1971), Dirty Harry, USA: Warner Bros., The Malpaso Company.

Vanzina, Stefano (1972), La polizia ringrazia (Execution Squad), Italy, France and West Germany: Dieter Geissler Filmproduktion, P.A.C., Primex Italiana.

\section{Contributor details}

Giulio Olesen is a Ph.D. student in Film Studies and Italian History at Bournemouth University. His research focuses on an Italian filone of the 1970s, the Poliziottesco, and its 
relationship to conflictive interpretations of the events that characterized the decade, such as political violence, terrorism and sensational kidnappings. His background in Sociology and Journalism influenced his approach towards Film Studies and his previous works on the Italian Comedy of the 1950s, and on the spaghetti western filone of the 1960s.

\section{Contact:}

Faculty of Media and Communication, Bournemouth University, BH12 5BB, UK.

E-mail: giulioolesen@hotmail.com

Note

\footnotetext{
${ }^{1}$ Song'e Napule was released in the United Kingdom with its original title that is a pun that mixes English and Neapolitan dialect: Song refers to the English noun Song (because the action is centred on neo-melodic Neapolitan musicians) but also to the Neapolitan dialect verb Song ('I come from'). Thus, the title plays with the double meaning 'Song from Naples' and 'I come from Naples'.
} 